\title{
Tapping the Potential of Processed Food Production Based Small and Medium Enterprises as Economic Drivers in Malang Regency
}

\author{
Stefanus Yufra M. Taneo ${ }^{1}$ \\ Etsa Astridya Setiyati ${ }^{2}$ \\ Melany $^{3}$ \\ Sri Hadiati ${ }^{4}$ \\ 1,2,3,4 Universitas Ma Chung. Email correspondence: stefanus.yufra@machung.ac.id
}

\begin{abstract}
Food Processing Industry gives the biggest contribution to Gross Regional Domestic Product (PDRB) of Malang Regency during 2010 until 2014; but unfortunately, it has not developed optimally yet, especially to increase the income of small and medium entrepreneurs. This study aims to (1) identify the types of production based SMEs within this industry which are potential to drive the economy of the District in Malang Regency, and (2) investigate the factors which may affect the production of these SMEs. Data were obtained from the Industry and Commerce Department of Malang Regency. Location Quotient (LQ) analysis tool was employed to identify the type of food production based SMEs that are potential to become the driving force for the regional economy. In addition, multiple linear regression was used to determine the effect of the amount of labor, equipment investment, and raw material costs on the production of processed food types. The results of the identification find that there are three types of food production based SMEs (that are generated by most of 33 districts in Malang Regency), namely (1) bread and pastries, (2) chips, and (3) crackers. The result of $L Q$ analysis shows that bread and pastry SMEs become the economic driver in Dau, Gedangan, Singosari, Sumberpucung, Wagir, and Wajak subdistricts. Chips SMEs become the economic driver in Ampelgading, Pagelaran, Pakis, Tirtoyudo, Turen and Wajak subdistricts. Meanwhile, Crackers SMEs become the economic driver in Bululawang, Donomulyo, Sumbermanjing Wetan, Turen, and Wajak subdistricts. From the perspective of equity aspect in economic development, the findings of this research is deemed to be interesting, because it shows that most sub-districts whose food production based SMEs become the economic driver are located in South Malang (except Singosari, Dau, and Pakis subdistricts) in which economic condition of the people is lower than that of the rest of Malang Regency.
\end{abstract}

Keywords: SMEs, LQ, commodity base, processed food, Malang 


\section{Introduction}

Micro, Small and Medium Enterprises (MSMEs) play an important role in the national economy. In 2013 there were 57.9 million MSMEs in Indonesia (about 99.9 percent of the total business units), which absorbed 114.1 million people (about 97 percent of the workforce), and contributed around Rp5,440,007.9 billion (60 percent) to the national Gross Domestic Product (GDP) (Ministry of Cooperatives and SMEs, 2016). However, the contribution of SMEs to non oil and gas exports is still considered small (2.76\% for Small Business and $11.54 \%$ for Medium Enterprises) compared to Big Enterprises (84.32\%).

The low contribution of SMEs to non-oil and gas exports indicates that the competitiveness of Indonesian SMEs is low. The low competitiveness of SMEs is affected by many factors. Cho and Moon (2003) identify nine factors as determinants of competitiveness in developing countries (including Indonesia), namely: (1) entrepreneurs - who are the source of innovation; (2) politicians and bureaucrats or governments; (3) workers; (4) professional managers and engineers; (5) resources or factors of production; (6) demand; (7) related and supporting industries; (8) business environment, i.e. corporate strategy, structure and competition among companies within the industry; and (9) opportunities derived from external factors.

The small, medium-sized food industry is also affected by the nine competitiveness factors. The entrepreneurs often also act as workers and managers (business managers). Local governments play a role through various regulations and policies that determine the growth and development of SMEs food. Factors of production are raw materials, place of business, labor and other necessities to produce processed food. Demand, in this case, is consumers who need food products. Meanwhile, related industries and supporters may include industries that produce seasoning, cooking oil, and offer packing and transportation service. The business environment and external factors will also determine the level of competition in the small, medium-sized food industry (SMFI).

SMFI is considered to be a strong production base for Indonesia in the current ASEAN Economic Community (MEA) era. The purpose of the MEA is to create a single market and production base through the free flow of goods, services, capital, investment, and skilled labor (ASEAN, 2008). If the production base of a country is not strong or competitively low, then ASEAN countries (including Indonesia), will only become product markets of other countries. One of the concepts proclaimed to increase the production base of small and medium industries in Indonesia is One Village One Product (OVOP) concept.

In Malang, Yusriansyah's (2014) research concludes that Tempe chips industry become a high value-added product of Malang area because the material is easy to acquire from the surrounding community, and the productivity of the industry is high with monthly income between IDR 10 million and 20 million. The high productivity and income are influenced by the high number of domestic and foreign tourists who visit Malang area. These tourists usually buy processed food as souvenirs and gifts for family and friends. In 2014 there were 5.8 million domestic and foreign tourists visiting Malang, and this number increased to 6.4 million by 2015 since Malang has become a tourist destination (Suryamalang Online News, 2016). 
This shows the great economic potential of the food industry in Malang. Ferdinand (2014) in his research on the development strategy of Tempe cluster SMEs in Sanan Malang recommends development strategy as follows: 1) forming a business community of Tempe chips; 2) business scale development; 3) increased government support.

Although One Village One Product (OVOP) concept has long been declared, unfortunately, information regarding the specialization of small geographic areas (villages or sub-districts) in producing one type of processed food products in Malang Regency region is limited. This research is conducted to fill the aforementioned research gap, with the aim of providing scientific information about the type of food industry which become the basis of each District economic growth in Malang Regency area. The result of this study is expected to provide information for supporting the development of potential SMFI in each District.

\section{Literature Review}

\subsection{Small Medium-sized Food Industry}

Small and Medium Enterprises (IKM) food is classified as a processing industry and is part of Small and Medium Enterprises (SMEs). The Central Bureau of Statistics (BPS, 2016) defines the processing industry as an economic activity that converts basic goods mechanically, chemically, or by hand into finished or semifinished goods, or less valued goods into higher value goods. Small and Medium Enterprises (SMEs) are more extensive, including production, distribution, marketing, and other activities including services such as transportation, packing, and milling. In practice, however, these two terms are often equated and used interchangeably.

Delineation of SMEs varies according to many authors and institutions. The commonly used delineation is based on Law Number 20 The year 2008 on Micro, Small and Medium Enterprises, which views the business size according to its net worth and annual sales. In addition, the criteria suggested by Statistics Indonesia (BPS/Badan Pusat Statistik) is often utilized. The criteria are based on the number of workers, i.e. enterprises which employ 5 to 19 workers will be categorized as Small Business and those which employ 20 to 99 workers will be classified as Medium Enterprises. In short, SMEs are those enterprises which employ between 5 to 99 people as their workforce.

\subsection{Base Sector as Drivers of Economic Development}

Business development has to deal with limited resources. Therefore, the development of SMFI needs to be done effectively and efficiently by developing industries which have a comparative advantage. Location Quotient (LQ) is one of the methods used to identify commodities or superior products that have a comparative advantage within a region (Miller \& Wright, 2001, Hood, 2008). The LQ technique is one of the most common approaches used in the basic economic model as a first step to identify sectors of activity that triggers growth (Hood, 2008).

Rusastra et al. (2002) define base sector as outward-oriented (either regionally, nationally or internationally) community activity. The concept of technical 
and economic efficiency is crucial for the growth of a region's base. Meanwhile, nonbase activities are community activities which result in goods and services intended for the community within the community's economic area.

The basic economic model explains that the direction and growth of a region are determined by regional exports. Exports are not limited to goods and services, but also in the form of expenditures of foreigners residing in the region against immovable goods (Budiharsono, 2001). In practice, the widespread use of LQ techniques is not limited to economic discussions but also to determine the distribution of commodities or to identify areas based on their potential.

This technique has several assumptions: (1) that all residents in a region have the same demand pattern as the pattern of reference area demand; and (2) that the productivity of each worker in each industry sector is equal to the productivity of the worker in the reference area, 3) every industry produces homogeneous goods in every sector, and (4) that the nation's economy is a closed economy (Hood, 2008). The last assumption is difficult to occur in today's economic conditions.

LQ analysis has several advantages and limitations (Hood, 2008; Warpani, 2001). The advantages of LQ analysis include a simple analysis tool that can exhibit the economic structure of a region and potential import substitution industry or products that can be developed for export and indicate potential industries (sectoral) for further analysis. LQ analysis is also used to calculate the potential of superior products from the utilization of natural resources in the sectors of agriculture, plantation, fishery, livestock, forestry and tourism in some areas. It can also indicate which areas are most potential for certain products to be established as a base or non-base region. Miller \& Wright (2001) explicitly states the following advantages of LQ analysis: (1) it can be utilised easily and quickly, (2) as a preliminary analysis tool for an area that can be followed up with other analytical tools; (3) can be counted repeatedly for any change of specialization by using various reference variables and time periods, and (4) changes in the degree of specialization can be identified by comparing $L Q$ from year to year.

Miller \& Wright (2001), on the other hand, explain that the LQ analysis tool has some limitations, such as (1) it is a descriptive rough indicator, (2) it is a tentative conclusion, (3) does not pay attention to the economic structure of each region, and (4) time lag problems. The time lag problem has two consequences. First, the base multiplier or multiplier does not take place precisely because it requires time lag between the response of the base sector to the demand from outside the region and the response from the non-base sector to the changes in the base sector. Second, usually the time lag issue in most cases is ignored, but in the long run, this problem is most likely to happen.

\section{Methodology}

This research was conducted in Malang Regency considering that Malang is one of the main tourist destinations in Indonesia, and tourists usually buy processed food as souvenirs or gifts when returning to their hometown or country of origin. In this case, the processed food industry needs to receive special attention from the local governments and business actors to optimize the potential of the region, and in order 
to produce processed foods that are of high competitive advantage. This study provides information about the type of food industry that becomes the basis of economic drivers in Malang. Furthermore, Malang Regency is the second largest area in East Java Province and is one of the important agricultural producing centers in Indonesia that provides raw materials for national food processing industry (Badan Pusat Statistik, 2017).

This study analyzes secondary data that are available from Industry and Trade Bureau of Malang Regency. Malang Regency consists of 33 districts. Available data include the type of SMFI, corporate identity, and the amount of production that is produced every year in each Kecamatan (District). The available data shows the conditions in 2015. Each type of industry is calculated with regards to its distribution in each District, and the result indicates that there are three major SMFI in Malang Regency, namely Bread, Cake, and Cookies; Chips, and Crackers. Chips and Crackers are made from various types of raw materials (both fruits and vegetables). The data obtained than were analyzed using Location Quotient (LQ) method using the following formula (Hood, 2008):

$$
\mathrm{LQ}=\left(\mathrm{X}_{\mathrm{ij}} / \mathrm{X}_{\mathrm{i}}\right) /\left(\mathrm{X}_{\mathrm{ij}} / \mathrm{X}_{\mathrm{j}}\right)
$$

where:

$X_{i j}=$ the amount of certain type food industry production in a Kecamatan (District)

$X_{i}=$ the total amount of food industry in a Kecamatan (District)

$X_{j}=$ the total amount of certain type food industry in Malang Regency

$X=$ the total amount of food industry in Malang Regency

LQ analysis techniques help to identify the types of food products that are the basis for driving economic growth in a District. The value of $L Q>1$ is called the base sector, indicating the concentration of production of certain types of food industries in a District when compared to the relative activity of the food industry in Malang Regency. In other words, there is a surplus of production in an industry type, and the type of food industry is a base sector in the District. If the value of $L Q=1$, then this indicates that the relevant District has a certain food industry activity which is equivalent to the activity of the food industry in Malang Regency. If the value of LQ $<1$, called the non-base sector, then this indicates that the district has a relatively smaller market share compared with certain food industry activity in Malang Regency. In other words, there was a deficit in the production of the food industry in the District.

\section{Findings and Discussion}

\subsection{Findings}

The identification of base industry using Location Quotient (LQ) approach indicates that there are three types of potential IKM that are: (1) bread, cake, and cookies industry; (2) chips industry (in which the chips are made from various kind of vegetables and fruits); and (3) cracker industry (in which the cracker is made from 
various raw materials). Table 1 exhibits the calculation of LQ for bread, cake, and cookies SMFI and indicates that this industry is the economic base in 7 Districts out of 11 Districts that have bread, cake, and cookies SMFI. This means that the industry becomes the main driver of economic growth in the 7 districts.

Table 1

Identification of Bread, Cookies and Cake SMFI as a Base Industry in Malang Regency

\begin{tabular}{llrc}
\hline No. & Kecamatan/Districs & LQ & Results \\
\hline 1 & Ampelgading & 18.470 & Base Industry \\
2 & Bululawang & 0.025 & Non-base industry \\
3 & Dampit & 0.088 & Non-base industry \\
4 & Dau & 0.032 & Non-base industry \\
5 & Gondanglegi & 0.799 & Non-base industry \\
6 & Pagelaran & 10.644 & Base Industry \\
7 & Pakis & 6.730 & Base Industry \\
8 & Tirtoyudo & 5.227 & Base Industry \\
9 & Turen & 9.830 & Base Industry \\
10 & Wagir & 17.716 & Base Industry \\
11 & Wajak & 7.860 & Base Industry \\
\hline
\end{tabular}

Source: Industry and Trade Bureau of Malang Regency data analysis result (2017)

Table 1 exhibits that if bread, cake, and cookies SMFI are developed in Malang Regency, especially in 7 districts that are identified as base industries, it will drive economic growth through labor absorption, raw material use, and product sales. In addition to bread, cake, and cookies SMFI, potential SMFI in the area of Malang Regency are fruit and vegetable chips industry which produces various type of chips such as jackfruit chips, cassava chips, taro chips, potato chips, mushroom chips, and many others. The result of LQ analysis (Table 2) shows that the chips industry can be considered as a base industry in 5 districts in Malang Regency.

Table 2

Identification of Chips Industry as Base Industry in Malang Regency

\begin{tabular}{llrc}
\hline No. & Kecamatan/Sub-districs & LQ & Results \\
\hline 1 & Dampit & 0.105 & Non base \\
2 & Dau & 17.042 & Base Industry \\
3 & Gedangan & 17.716 & Base Industry \\
4 & Kepanjen & 0.665 & Non base \\
5 & Lawang & 0.210 & Non base \\
6 & Pakis & 0.072 & Non base \\
7 & Singosari & 1.836 & Base Industry \\
8 & Sumberpucung & 17.716 & Base Industry \\
9 & Turen & 0.129 & Non base \\
10 & Wagir & 17.716 & Base Industry \\
\hline
\end{tabular}

Source: Industry and Trade Bureau of Malang Regency data analysis result (2017) 
The last type of potential SMFI that is identified using LQ approach is the Crackers industry (which processes various raw materials into crackers). The calculation results are presented in Table 3.

Table 3

Identification of Cracker Industry as the Base Industry in Malang Regency

\begin{tabular}{llrl}
\hline No. & Kecamatan/Districs & \multicolumn{1}{c}{ LQ } & Results \\
\hline 1 & Bululawang & 15,146 & Base Industry \\
2 & Donomulyo & 389,988 & Base Industry \\
3 & Lawang & 0,390 & Non-base \\
4 & Sumbermanjing Wetan & 374,304 & Base Industry \\
5 & Turen & 49,675 & Base Industry \\
6 & Wajak & 172,543 & Base Industry \\
\hline
\end{tabular}

Source: Industry and Trade Bureau of Malang Regency data analysis result (2017)

Cracker Industry was only available in 6 districts in Malang Regency in 2015. The analysis shows that cracker industry is the base industry in almost all districts that produce crackers, except in Lawang District.

\subsection{Discussion}

The LQ analysis shows that bread, cake, and cookies SMFI are the base industry and potential to be the trigger of economic growth in seven Districts out of eleven districts that produce bread, cake, and cookies. Bread, cake, and cookies SMFI products in these Districts are well-known for (1) good taste and low price, (2) freshly made without added preservatives, (3) ready to eat, and (4) can be customized according to customer needs and wants.

Bread, cake, and cookies SMFI that use raw materials of various types of food have backward linkage and strong forward linkage and therefore can have a big economic impact. Backward linkages related to primary agriculture providing raw materials; while future linkages are related to consumers. The development of the processing industry must be implemented in an integrated and directed way through an integrated policy which covers the entire chain of agribusiness and agro-industry systems, from upstream to downstream.

Bread, cake, and cookies SMFI require flour ingredients from a variety of sources such as rice, corn, and sweet potatoes, eggs, spices, which are available abundantly in the area. Therefore, the raw material of this industry is easy to obtain so it can cut costs and can be offered at an economical price to the consumer. In addition, in the process of production and distribution, the industry uses human resources that absorbs much local labors. Rahmawati's study (2016) finds that capital and labor significantly affect bread production, but raw materials and the length of business experience did not significantly affect bread production in Bojongloa Kaler District (bread production center), Bandung. Results of Purnawan et al. (2012) research also find that small and medium-sized bakery and cake industries in Bogor City are potential to be developed using market penetration and product 
development strategies. Market penetration strategy should be implemented through expanding the marketing network area by cooperating with existing counters in the selected culinary tourism destination or opening a new branch at tourist area outside Bogor.

The finding of Rahmawati's research (2016) that raw materials have no significant effect on bread production does not mean that the raw material is not important. Kaluntas et al. (2016) explain that most small businesses do not have raw material inventory management. Therefore, many small businesses have not been able to calculate the optimal purchase of raw materials which then resulted in higher raw material purchase cost. The same result was found by Toar et al. (2016) that small businesses are inefficient in the cost of production which causes the cost of production is too high and unable to compete.

The high cost of bread production may be influenced by the increasing wheat flour consumption in Indonesia. It is noted that there is a $5.61 \%$ consumption increase happen (from 1.15 million tons in 2011 to 1.22 million tons) in 2012 (Aptindo, 2012). The increase of wheat consumption is driven by the growth of wheat flour-based downstream industry such as biscuit, instant noodle and crumbed bread in Indonesia. This illustrates that people prefer processed foods made from wheat, whereas wheat-based wheat is imported products since Indonesia has not been able to produce wheat economically. One of the efforts to build food security is by developing substitution materials that can reduce imported commodities. One of the imported flour substitution products is mocaf (modified cassava flour). Mocaf is a modification of ordinary cassava flour by fermentation, using lactic acid bacteria, acetic acid or enzymes (Fadilah et al., 2015). The fermentation treatment produces cassava flour which has a soft, white, odorless and has similar characteristics to flour. Fadilah et al. (2015) conducted a study to identify consumer attitudes toward various attributes of donuts made from wheat flour and mocaf. The results indicate that the taste attributes and texture attributes were considered to be considered by consumers in the selection of donut products, and there was no significant difference in consumer attitudes toward donuts with various level of mocaf substitutions.

Cassava has become a superior product in the Sukowolangun Village, Kalipare District. Total production reaches 7,200 tons per year and is only marketed locally (Malang Regency's Body of Planning and Development, 2014). The availability of cassava in Kalipare Subdistrict and abundant in Indonesia can be an alternative to realize food security. Cassava is a plant that is very easy to be cultivated in bulk. Cassava plant has a wide adaptation and therefore its utilization can be optimized to encourage economic growth in Malang Regency as well as in Indonesia in general.

Although bread, cake, and cookies SMFI are not efficient in terms of production costs they are found to be able to innovate products. Saputri et al.'s research (2015) find that bread, cake, and cookies SMFI innovate products in the following ways: (1) modulation based innovation; (2) size-based innovation; (3) packaging-based innovation; (4) design-based innovation; and (5) innovation-based development of complementary materials. Product innovation should also be accompanied by improvements at the production level. Research Tisnowati et al. 
(2008) states that the cause of poor quality of bread often occurs due to raw material, equipment and machinery problems, personnel, and production processes.

Raw material innovation (especially using local raw materials) has the potential to create disruptive innovation. The disruptive innovation criterion according to Markides (2012) is an innovation that should start as an inferior in terms of performance by consumers, but superior in price and well-developed in performance. Local food raw materials are viewed inferior by consumers but are superior in price because they are cheap. However, over time, local foodstuffs can be superior in performance as their quality improves and can become functional food. Hassan's research (2014) demonstrates the potential and development of flour-based industries based on local raw materials as functional foods thus increasing their added value. Several types of local food that have the potential to be developed as raw materials for flour processing include bananas, yam, pumpkin, taro, corn, sago, and breadfruit. The result of Hassan's (2014) study proves that various types of local food have certain physiological functions that are beneficial to health. Laboratory studies conducted by Halim et al. (2015) find composite flour formulations (which is composed of wheat flour, sago starch, and Tempe flour) produced the best bread in terms of nutritional value and the quality of the sweet bread was in line with Indonesian national standards.

With regards to Chips SMFI, the analysis shows that chips SMFI are considered to be a base industry in the South (Gedangan and Sumberpucung), West (Dau and Wagir), and North (Singosari and Wagir) area Malang Regency. Considering the availability of raw material sources, this industry is more potential to be developed in the South and East regions of Malang Regency (Dampit, Kepanjen, Pakis, and Turen). Chips with raw materials from agricultural products are one of the largest potentials in Southern Malang district. Agricultural, livestock and fishery sectors (agro fields) account for approximately 29\% of GRDP. Products of this agro field that are often used as raw materials for chips industry including fruits, cassava, sweet potatoes, taro, and plantation products.

Chips SMFI products can trigger economic growth through the creation of added value. The results of Nurmedika et al.'s study (2013) show that the turnover earned by Tiara household industry in producing jackfruit chips during July 2012 is IDR 58.5 million, generate income of IDR 36,307,614.25 and added value of IDR $33.169 / \mathrm{kg}$. Another study conducted by Hamidah et al. (2015) concerning the processing of cassava into cassava chips concluded as follows: (1) cultivating cassava into cassava chips causes added value to the cassava commodity (since cassava product quality can be maintained for longer time, consumer acceptability can be improved and marketing distribution can be expanded); (2) Processing yams into chips can also increase the added value of its economy, i.e. the price is relatively high and stable compared to unprocessed yam (from the average price of IDR 2.760 / kg of cassava to IDR 52,000 / kg of yam chips); and (3) the added value gained in the business of yam chips agroindustry is IDR $25.231 / \mathrm{kg}$ or equal to $78.8 \%$ and generate profits for entrepreneurs around IDR $24.269 / \mathrm{kg}$ (which is around $95.6 \%$ ).

Besides processed into chips, cassava is also potential to be processed into wheat flour substitute meal. Utami and Dumasari (2014) suggest a strategy that can be implemented in developing locally processed food products made from cassava 
raw material by maintaining the taste and uniqueness of local products and forming agribusiness clusters to strengthen the agribusiness system of cassava plantation from the beginning stage of cassava cultivation to the production of various cassava products.

The result of $L Q$ analysis finds that all districts which have Crakers SMFI base are located in the Southern region of Malang Regency. The Southern region of Malang Regency has great potential in the production of food crops, farming, livestock, fishery, and forestry, as raw materials for the industry of crackers. If the potential of agricultural products can be optimized, such as through the cracker industry, this will encourage economic growth of South Malang, thus minimizing its disparity compared to North Malang.

Mangrove plants, which are available in Malang Regency, are not only important for nature conservation, but the fruit can also be processed into flour as the basic ingredients of crackers. Research conducted by Puspitasari (2015) proves that mangrove fruit crackers (R.mucronata) through certain processing can reduce tannin level by $34 \%$.

Southern Malang Regency has great potential from fisheries sector. Fish, in addition to fresh consumption, can also be processed into a variety of products, including crackers. The results of the Wahida et al.'s study (2015) shows that fish cracker business (especially Sillago sihama fish) has great economic potential. Business licenses such as SIUP, TDI, PIRT, trademark registration, and halal certificates are now easily acquired. On the technical aspect, facilities and infrastructure are easily obtained. In the long-term, the financial aspect of fish cracker business is feasible to run up to 10 years into the future. With regards to marketing and business development strategy, entrepreneurs may gain competitive advantage through product diversification strategy.

Food crops such as maize are also very potential in Southern Malang Regency. Corn can be obtained from a wide range of products including crackers. Agato and Narsih (2011) reported the results of research on the manufacture of corn milk with the addition of CMC (Carboxymethyl Cellulose) and corn crackers (with the determination of the composition of flour based on the condition of corn pulp and boiling process). The results of his research have been disseminated to the community of one of the corn producing villages. In the training of corn milk and corn crackers, $100 \%$ of partners can make corn milk, corn crackers, and pack well. The product of the training is physically attractive and taste so that it can be accepted both visually and organoleptically.

Small and Medium Food Industry in Malang Regency is dominated by agriculture sectors with have to deal with major constraint in the form of business capital (Bappeda of Malang Regency, 2017). Therefore, the Government of Malang Regency established the Technical Implementation Unit (UPT) of Revolving Fund which aims to provide working capital credit facilities for existing cooperatives and MSMEs. The program is expected to encourage SMFI to improve its performance to be able to drive economic growth in Malang regency.

\section{Conclusion}


This study identifies three types of SMFI products that serve as the basis for driving economic growth in Malang Regency, namely (1) bread, cake, and cookies SMFI; (2) Chips SMFI; and (3) Crackers SMFI. Not all districts in Malang Regency have an industrial base, however, the potential outside the food processing industry sector can still be explored further.

Small and Medium Food Industries that utilize agricultural products have great potential in improving economic growth. In addition, SMFI sector should be managed optimally since it has the potential to reduce economic inequality between the Southern and Northern parts of Malang Regency. In other words, the development of SMFI in Malang Regency may promote inclusive economic development.

\section{References}

ASEAN. 2008. ASEAN Economic Community Blueprint. Jakarta: ASEAN Secretariat.

Bappeda (Badan Perencanaan Pembangunan Daerah) Kabupaten Malang. 2014. Profil Produk Unggulan di Kabupaten Malang.

Budiharsono, S. 2001. Teknik Analisis Pembangunan Wilayah Pesisir dan Lautan. Jakarta: PT Pradnya Paramita.

Cho, Dong-Sung dan Hwy-Chang Moon. 2002. From Adam Smith to Michael Porter: Evolution to Competitiveness Theory. New Jersey: World Scientific.

Fadilah, A.N., Widodo, Widodo, A.S. 2015. Sikap Konsumen Terhadap Produk Donat Berbahan Mocaf sebagai Pengganti Tepung Terigu. Jurnal Agraris, 1 (2): $149-156$.

Ferdinand. 2014. Strategi Pengembangan Klaster Usaha Mikro Kecil dan Menengah Keripik Tempe di Sanan Malang. Jurnal Aplikasi Manajemen, 14 (1): $1-13$.

Hamidah, M., Yusra, A.H.A., dan Sudrajat, J. 2015. Analisis Nilai Tambah Agroindustri Kripik Ubi di Kota Pontianak. Jurnal Social Economic of Agriculture, 4(2): 60-73.

Hood, R. 2008. Economic Analysis: A Location Quetient. Primer: Principle Sun Region Association, Inc.

Miller, M.M. and G.N. Wright. 2001. Location Quotient Basic Tool for Economic Development Analysis. Economic Development Review, 9(2); 65-78.

Nurmedika, Marhawati, M., dan Alam, M. N. 2013. Analisis Pendapatan dan Nilai Tambah Keripik Nangka pada Industri Rumah Tngga Tiara di Kota Palu (Analysis of Income and Added Value of Jackfruit to Jackfruit chip by Home Industry "Tiara" in Palu). e-J. Agroteknis, 1 (3): 267-273.

Purnawan, A.H., Lombong, W.H., and Hartoyo, S. 2012. Kajian Pengembangan Usaha IKM Pangan Komoditas Roti dan Kue di Kota Bogo (Studi Kasus Bownies Elsari, Bogor). (The Bogor's Cake and Bakery Small-Medium Industries Development Analyses: Elsari Brownies and Bakery Bogor Case Study). Manajemen IKM, 7 (1): 74-84.

Puspitasari, S.D.Y.E. 2015. Kerupuk Mangroveantidiare Dari Buah Bakau Rhizopora Mucronata (Antidiare Mangrove Crackers Fromrhizopora Mucronata Fruit). Journal of Innovation and Applied Technology (JIAT), 1 (1): 82-87. 
Saputri, Y.R., Sasongko, and Julianto, D.E. 2015. Inovasi Produk pada Roti Ceria di Jember. e-SOSPOL XXX.

Tisnowati, H., Hubeis, M. and Hardjomidjojo, H. 2008. Analisis Pengendalian Mutu Roti (Kasus PT. AC, Tangerang). Jurnal MPI, 3 (1): 51-61.

Toar, A.P., Sondakh, J.J., and Kalalo, M.Y.B. 2016. Analisis Varians Biaya Produksi sebagai Alat untuk Mengukur Tingkat Efisiensi Biaya Produksi pada UD. Sedap Jaya Bakery. Jurnal Berkala IImiah Efisiensi, 16 (3): 596-604.

Undang-Undang Republik Indonesia Nomor 20 Tahun2008 tentang Usaha Mikro, Kecil, dan Menengah.

Utami, P. dan Dumasari. 2014. Strategi Pengembangan Usaha Bisnis Pangan Lokal Olahan Ubikayu di Kabupaten Banyumas. Agritech, XVI (2): 129 138.

Wahida, A.M., Primyastanto, M. dan Utami, T.N. 2015. Pengembangan Usaha Kerupuk Ikan Payus (Elops Hawaiensis) Pada Ud. Sumber Rezeki Kelurahan Gunung Anyar Tambak, Kecamatan Gunung Anyar, Kota Surabaya, Jawa Timur. Jurnal ECSOFiM, 3 (1): 39-47.

Warpani, Suwardjoko. 2001. Analisis Kota danDaerah, Penerbit ITB, Bandung

Yusriansyah, M. 2014. Karakteristik Pengusaha Industri Keripik Tempe Berbasis Produk Unggulan Di Kota Malang. http://jurnal-online.um.ac.id/data/artikel/ artikel90579CD71C9ECAA8FF59C8A9C75C75B8.pdf; diakses tanggal 16 September 2017. 